DOI: 10.15503/onis2014-242-251

\title{
PERFEKCJONIZM - POZYTYWNY CZY NEGATYWNY? ADAPTACYJNE I DEZADAPTACYJNE FORMY PERFEKCJONIZMU
}

\author{
Elżbieta Sanecka, e.sanecka@wp.pl \\ Uniwersytet Śląski w Katowicach \\ Bankowa 12, 40-007 Katowice
}

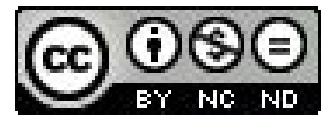

\section{STRESZCZenie}

Perfekcjonizm rozumiany jako cecha osobowości, definiowany jest najczęściej w ramach modeli unidymensjonalnych, dychotomicznych lub wieloczynnikowych. Dominujące podejścia teoretyczne koncentrują się nie tylko na dysfunkcjonalnych, negatywnych aspektach perfekcjonizmu związanych z symptomami psychopatologii, ale też wskazują na istnienie pozytywnego, adaptacyjnego wymiaru perfekcjonizmu. Celem artykułu jest omówienie i analiza koncepcji teoretycznych oraz dotychczasowych wyników badań empirycznych poświęconych obydwu formom perfekcjonizmu. Szczególną uwagę poświęcono analizie czynników modyfikujących związek perfekcjonizmu z symptomami psychopatologii.

Słowa kluczowe: perfekcjonizm, cecha osobowości, obsesyjno-kompulsyjne zaburzenie osobowości, sumienność

\section{Perfectionism - positive or negative? Adaptive and maladaptive forms of perfectionism}

\section{Abstract}

Perfectionism as a personality trait is defined in the frame of unidimensional, bidimensional or multifaceted models. The dominating theoretical approaches not only concentrate on the dysfunctional, negative aspects of perfectionism related to the symptoms of psychopathology, but they also indicate the presence of a positive, adaptative dimansion of perfectionism. The aim of the article is to discuss and analyze theoretical concepts and the results of previous empirical research concerning both forms of perfectionism. Special attention was focused on the analysis of the factors modifying the relation between perfectionism and symptoms of psychopathology.

Key words: perfectionism, personality trait, obsessive compulsive personality disorder, conscientiousness

\section{WPROWADZENIE}

Na gruncie psychologii perfekcjonizm definiowany jest zazwyczaj jako „cecha osobowości przejawiająca się w dażeniu do doskonałości, wyznaczaniu sobie zawyżonych standardów wykonania zadania w połączeniu z nadmiernym samokrytycyzmem i przypisywaniem zbyt dużego znaczenia opiniom innych na temat jednostki oraz jej pracy"1. Inne wyznaczniki perfekcjonizmu obejmują: utożsamianie poczucia własnej wartości oraz samooceny z poziomem realizacji zadania, samokaranie się w przypadku doświadczania porażki, brak satysfakcji z odniesionego sukcesu, skłonność do podtrzymywania zbyt wysokich oczekiwań wobec siebie lub innych, przyjmowanie nierealistycznych wyznaczników sukcesu, a także szerokich kryteriów, w oparciu o które określone działanie kwalifikowane jestjako porażka². Charakterystykom tym zazwyczaj towarzyszą specyficzne formy autoprezentacji, związane z promowaniem idealnego wizerunku własnej osoby oraz skłonnością do ukrywania własnych niedoskonałoścỉ.

Pomimo że w tradycyjnym ujęciu perfekcjonizm kojarzony był najczęściej z wymiarem psychopatologii, nowsze konceptualizacje wskazują na istnienie pozytywnej, adaptacyjnej, zdrowej czy też funkcjonalnej postaci tego zjawiska", która najczęściej utożsamiana jest przez badaczy i teoretyków z sumiennością bądź dążeniem do osiągnięć i perfekcji ${ }^{5}$.

1 P. Hewitt, G. Flett, Perfectionism in the self and social contexts: conceptualization, assessment, and association with psychopathology, "Journal of Personality and Social Psychology" 1991, nr 60(3), s. 456; J. Stoeber, J. Childs, The assessment of self-oriented and socially prescribed perfectionism: subscales make a difference, "Journal of Personality Assessment" 2010, nr 92(6), s. 577.

2 P. Hewitt, G. Flett, When does conscientiousness become perfectionism?, "Currrent Psychiatry" 2007, nr 6(7), s. 50.

3 S. Sherry, P. Hewitt, G. Flett, D. Lee-Baggley, P. Hall, Trait perfectionism and perfectionistic self-presentation in personality pathology, "Personality and Individual Differences" 2007, nr 42, s. 488

4 J. Stoeber, K. Otto, Positive conceptions of perfectionism: approaches, evidence, challenges, "Personality and Social Psychology Review" 2006, nr 10, s. 295-296.

5 P. Hewitt, G. Flett, When does..., dz. cyt., s. 50; J. Stoeber, K. Otto, C. Dalbert, Perfectionism and the Big Five: conscientiousness predicts longitudinal increases in self-oriented perfectionism, "Personality and Individual Differences" 2009, nr 47(4), s. 363. 
W rezultacie w ciagu ostatniej dekady dominujące stało się podejście, w którym perfekcjonizm ujmowany jest jako złożony (dwu- lub wielowymiarowy) konstrukt. Tym samym, zgodnie z zyskującymi na popularności multidymensjonalnymi modelami perfekcjonizmu, większość psychologów przyjmuje, że w środowisku rodzinnym i zawodowym może on przybierać zarówno adaptacyjna, jak i dezadaptacyjną formę ${ }^{6}$.

Pozytywne aspekty orientacji perfekcjonistycznej wydają się związane z automotywacją, wysoką samoocena, satysfakcją z życia oraz bezpiecznym stylem przywiązania ${ }^{7}$. Natomiast perfekcjonizm w swej dezadaptacyjnej postaci może prowadzić m. in. do myślenia w kategoriach „,wszystko albo nic", prokrastynacji, autodeprecjacji, a także mniejszej efektywności, rozumianej jako stosunek liczby popełnianych błędów do czasu poświęconego na wykonanie zadania. Negatywny (zły czy też neurotyczny) perfekcjonizm wydaje się również wykazywać pozytywny związek z depresją, anoreksja, skłonnościami samobójczymi, zaburzeniami obsesyjno-kompulsywnymi, doświadczanym poziomem lęku i złości oraz innymi symptomami wskazującymi na istnienie problemów psychologicznych. Ponadto, dotychczasowe badania prowadzone w obszarze psychologii zdrowia i klinicznej pokazuja, że cecha ta ukazuje negatywny związek ze zmiennymi będącymi wskaźnikami pozytywnego afektu, szczęściem, optymizmem, samooceną i satysfakcją z życia9.

Szereg badań poświęconych pozytywnym i negatywnym aspektom perfekcjonizmu wskazuje na to, że w ciąu ostatnich piętnastu lat zagadnienie to znalazło szeroki oddźwięk w literaturze z zakresu psychologii pracy i organizacji, psychologii społecznej oraz psychologii osobowości, co pozwoliło na lepsze zrozumienie jego natury, determinantów oraz konsekwencji1 ${ }^{10}$. Niniejszy artykuł stanowi podsumowanie wyników wcześniejszych badań poświęconych perfekcjonizmowi, rozumianemu jako cecha osobowości, a także próbę odpowiedzi na pytanie o możliwość konceptualizacji adaptacyjnej i dezadaptacyjnej formy perfekcjonizmu, oraz wyznaczenia jego pozytywnych aspektów. Zaprezentowane zostaną również dominujące modele perfekcjonizmu proponowane w ramach podejścia dychotomicznego $\mathrm{i}$ wielowymiarowego.

\section{PerfekCJONIZM - RYS HISTORYCZNY}

Chociaż samo pojęcie perfekcjonizmu pojawiło się literaturze psychologicznej już w pierwszej połowie ubiegłego wieku, okres wzmożonego zainteresowania tym zjawiskiem rozpoczął się dopiero pod koniec lat siedemdziesiątych, kiedy to Don Hamachek zaproponował wyróżnienie dwóch typów perfekcjonizmu: normalnego i neurotycznego. Pierwszy z nich miał znajdować wyraz w wyznaczaniu sobie przez jednostkę realistycznych wymagań, odczuwaniu zadowolenia ze starannie wykonanej pracy oraz zdolności do obniżania poziomu dokładności w sytuacji, gdy jest to konieczne. Z kolei perfekcjonizm neurotyczny definiowany był jako tendencja do stawiania sobie zazwyczaj nieosiągalnych standardów wykonania, doświadczanie poczucia, że podejmowane wysiłki są niewystarczające, a także niezdolność do rezygnacji z wcześniejszych założeń odnoszących się do poziomu realizacji zadania. Koncepcja ta, eksponując pozytywny, funkcjonalny, adaptacyjny wymiar perfekcjonizmu, w bezpośredni sposób nawiązywała do opisanego przez Alfreda Adlera dążenia do bycia perfekcyjnym, które to stanowiło jego zdaniem jeden z głównych motywów determinujących dynamikę ludzkiej osobowości i wyznaczników zdrowia psychicznego ${ }^{11}$.

Konceptualizacja zaproponowana przez D. Hamacheka stała w sprzeczności z dominującym w latach osiemdziesiątych, jednowymiarowym podejściem do perfekcjonizmu, który oceniany był przez większość badaczy oraz teoretyków jako neurotyczny, dysfunkcjonalny, a zatem stanowiący indykator psychopatologii. Stanowisko to nawiązywało do trady-

6 G. Flett, P. Hewitt, The perils of perfectionism in sports and exercise, "Current Directions in Psychological Science" 2005, nr 14(1), s. 14; J. Stoeber, K. Otto, C. Dalbert, Perfectionism and the Big Five..., dz. cyt., s. 363-364; H. Yang, J. Stoeber, The Physical Appearance Perfectionism Scale: development and preliminary validation, "Journal of Psychopathology and Behavioral Assessment" 2012, nr 34(1), s. 69.

7 K. Rice, J. Ashby, R. Stanley, Self-esteem as a mediator between perfectionism and depression: a structural equations analysis, "Journal of Counseling Psychology" 1998, nr 45(3), s. 304-305.

8 C. Bouchard, J. Rheaume, R. Ladouceur, Responsibility and perfectionism in OCD: an experimental study, "Behaviour Research and Therapy" 1999, nr 37(3), s. 239-241; P. Hewitt, C. Caelian, G. Flett, S. Sherry, L. Collins, C. Flynn, Perfectionism in children: associations with depression, anxiety, and anger, "Personality and Individual Differences" 2002, nr 32; S. Sassaroli, L. Lauro, G. Ruggiero, M. Mauri, P. Vinai, R. Frost, Perfectionism in depression, obsessive-compulsive disorder and eating disorders, "Behaviour Research and Therapy" 2008, nr 46, s. 757-759; J. Stoeber, M. Eysenck, Perfectionism and efficiency: accuracy, response bias, and invested time in proof-reading performance, "Journal of Research in Personality" 2008, nr 42(6), s. 1673-1674; J. Stoeber, K. Otto, Positive conceptions of perfectionism: approaches, evidence, challenges, „Personality and Social Psychology Review” 2006, nr 10, s. 295296; R. Winter, W pułapce perfekcjonizmu: prosta droga do porażki, Kraków 2013, s. 52.

9 A. Bergman, J. Nyland, L. Burns, Correlates with perfectionism and the utility of a dual process model, "Personality and Individual Differences" 2007, nr 43, s. 389, 1050-1052.

10 J. Stoeber, K. Otto, C. Dalbert, Perfectionism and the Big Five..., dz. cyt., s. 363-364.

11 D. Hamachek, Psychodynamics of normal and neurotic perfectionism, "Psychology" 1978, nr 15, s. 27-33; K. Szczucka, Polski Kwestionariusz Perfekcjonizmu Adaptacyjnego i Dezadaptacyjnego, „Psychologia Społeczna” 2010, nr 5, s.71.

OGRODY NAUK I SZTUK NR 2014 (4) 
cyjnego ujęcia perfekcjonizmu, wywodzącego się z nurtu psychodynamicznego, zgodnie z którym był on traktowany jako symptom neurotyzmu i zaburzeń osobowości. Wyniki badań empirycznych prowadzonych w tym okresie potwierdzały założenia modelu jednowymiarowego, wskazującego na dezadaptacyjny charakter perfekcjonizmu. W grupach pacjentów klinicznych zaobserwowano podwyższony poziom perfekcjonizmu wśród osób z diagnozą depresji, zaburzeń obsesyjno-kompulsyjnych oraz zaburzeń odżywiania. Podobne zależności odnotowano również w populacji ogólnej, w której perfekcjonizm dodatnio korelował z podwyższonym poziomem stresu, a także depresją, lękiem i zaburzeniami odżywiania. Warto podkreślić, że w badaniach tych wykorzystywano jednowymiarowe skale perfekcjonizmu (głównie skalę perfekcjonizmu autorstwa Davida Burnsa oraz podskalę perfekcjonizmu z Kwestionariusza Zaburzeń Odżywiania EDI) ${ }^{12}$.

W nowszych koncepcjach, dominujących w literaturze przedmiotu od pierwszej połowy lat dziewięćdziesiątych, perfekcjonizm ujmowany jest jako wielowymiarowy konstrukt, obejmujący zarówno osobowościowe, jak i społeczne komponenty, które w różnym zakresie mogą znajdować odzwierciedlenie w występowaniu objawów psychopatologii ${ }^{13}$. Taki sposób rozumienia perfekcjonizmu, bliższy koncepcji D. Hamacheka wydaje się w większym stopniu oddawać złożoność i istotę zjawiska, co sugerują wyniki badań empirycznych poświęconych negatywnym i pozytywnym aspektom perfekcjonizmu, prowadzonych począwszy od pierwszej połowy ostatniej dekady ubiegłego wieku ${ }^{14}$.

\section{WIELOWYMIAROWE MODELE PERFEKCJONIZMU}

Jedną z pierwszych multidymensjonalnych koncepcji perfekcjonizmu stanowiła konceptualizacja zaproponowana przez Randy 'ego Frosta, Patricię Marten, Cathleen Lahart i Robina Rosenblate `a, którzy stworzyli sześciowymiarowe narzędzie, stużące do pomiaru perfekcjonizmu ${ }^{15}$. W ramach zaproponowanego przez nich Wielowymiarowego Kwestionariusza Perfekcjonizmu (Frost Multidimensional Perfectionism Scale) wyróżnione zostały takie podskale, jak: standardy osobiste, obawa przed błędami, wątpienie w jakość swoich działań, zorganizowanie, oczekiwania oraz krytycyzm rodziców. Kwestionariusz ten wydaje się w większym stopniu odzwierciedlać dezadaptacyjny aspekt perfekcjonizmu ${ }^{16}$. Jednocześnie jego konstrukcja zwraca uwagę na etiologię opisywanego zjawiska związaną z czynnikami wychowawczymi (przede wszystkim autorytarnym stylem rodzicielskim) i transmisją międzypokoleniową norm i zachowań perfekcjonistycznych ${ }^{17}$.

Już jedne z pierwszych badań z wykorzystaniem tego narzędzia pokazały, że poszczególne wymiary perfekcjonizmu obecne w koncepcji R. Frosta i współpracowników były w różnym zakresie powiązane z miarami pozytywnego i negatywnego afektu. W szczególności obawa przed popełnieniem błędów, $\mathrm{w}$ tym ujęciu stanowiąca osiową charakterystykę perfekcjonizmu, wykazywała pozytywną korelację z lękiem, co zdaniem autorów wskazuje na silny związek tej podskali z występowaniem symptomów psychopatologii, towarzyszących negatywnej, dezadaptacyjnej formie perfekcjonizmu. Również późniejsze badania (prowadzone głównie w obszarze psychologii klinicznej i osobowości) ujawnily istnienie istotnej statystycznie, pozytywnej relacji między ogólnym poziomem perfekcjonizmu mierzonego za pomocą kwestionariusza FMPS a różnego rodzaju problemami psychologicznymi: lękiem przed rywalizacją wśród sportowców, lękiem przed oceną wśród studentów, prokrastynacją, bezsennościa, fobią społeczna, symptomami zaburzenia obsesyjno-kompulsyjnego, anoreksją i myślami samobójczymi ${ }^{18}$.

Pomimo znacznej popularności koncepcji R. Frosta i współpracowników, spośród wielowymiarowych modeli perfekcjonizmu najchętniej wykorzystywana na gruncie badań empirycznych, pozostaje alternatywna konceptualizacja zaproponowana przez Paula Hewitta i Gordona Fletta. Nawiązując do tradycyjnych koncepcji wywodzących się z praktyki klinicznej, zdefiniowali oni perfekcjonizm jako „neurotyczny styl osobowości obejmujący perfekcjonistyczne cechy osobowości, styl autoprezentacji i przekonania, które stanowią kluczowy czynnik odpowiedzialny za powstawanie różnego

12 J. Stoeber, K. Otto, C. Dalbert, Perfectionism and the Big Five..., dz. cyt., s. 363-365.

13 R. Frost, P. Marten, C. Lahart, R. Rosenblate, The dimensions of perfectionism, "Cognitive Therapy and Research", nr 14(5), s. 449; P. Hewitt, G. Flett, Perfectionism in the self..., dz. cyt., s. 456.

14 M. Enns, B. Cox, J. Sareen, P. Freeman, Adaptive and maladaptive perfectionism in medical students: alongitudinal investigation, "Medical Education" 2001, nr 35, s. 1035; J. Stoeber, K. Otto, C. Dalbert, Perfectionism and the Big Five..., dz. cyt., s. 363-364.

15 R. Frost, P. Marten, C. Lahart, R. Rosenblate, The dimensions..., dz. cyt., s. 449.

16 K. Szczucka, Polski Kwestionariusz..., dz. cyt., s. 72.

17 B. Soenens, A. Elliot, L. Goossens, M. Vansteenkiste, P. Luyten, B. Duriez, The intergenerational transmission of perfectionism: parents' psychological control as an intervening variable, "Journal of Family Psychology" 2005, nr 19(3), s. 359-360; K. Kawamura, R. Frost, M. Harmatz, The relationship of perceived parenting styles to perfectionism, "Personality and Individual Differences" 2002, nr 32(2), s. 317.

18 J. Stoeber, The Frost Multidimensional Perfectionism Scale: more perfect with four (instead

of six) dimensions, "Personality and Individual Differences" 1998, nr 24(4), s. 481-482. 
rodzaju problemów psychologicznych, fizycznych, zawodowych i interpersonalnych" ${ }^{\prime 19}$. Jednocześnie badacze wyróżnili trzy odrębne wymiary perfekcjonizmu ujmowanego jako: cecha osobowości: zorientowany na siebie (self-oriented), zorientowany na innych (other-oriented) oraz usankcjonowany społecznie (socially prescribed). Do pomiaru poszczególnych typów perfekcjonizmu stworzyli Wielowymiarowy Kwestionariusz Perfekcjonizmu (Multidimensional Perfectionism Scale), cechujący się dobrymi właściwościami psychometrycznymi ${ }^{20}$.

Pierwsza z wyróżnionych form opisywanej charakterystyki osobowości obejmuje szeroki zakres zachowań ukierunkowanych na siebie, takich jak wyznaczanie sobie rygorystycznych standardów wykonania zadania w połączeniu z dokonywaniem surowych i kategorycznych ocen odnoszących się do jakości własnej pracy. Zdaniem P. Hewitta i G. Fletta perfekcjonizm ukierunkowany na siebie zawiera ukryty komponent motywacyjny, przejawiający się zarówno w dążeniu do osiągnięcia perfekcji w swoich działaniach, jak i unikania porażek, a także przekonanie o tym, że bycie perfekcyjnym i dążenie do perfekcji mają istotne znaczenie. Dlatego też wykazuje związek z innymi zachowaniami ukierunkowanymi na siebie, takimi jak wysoki poziom aspiracji oraz samoobwinianie się. Ponadto, jest powiązany z różnorodnymi wyznacznikami nieprzystosowania do środowiska, obejmującymi między innymi podwyższony poziom lęku, anoreksję, subkliniczną depresję oraz niski poziom szacunku dla samego siebie.

Drugi wymiar perfekcjonizmu - perfekcjonizm zorientowany na innych - przejawia się w wyznaczaniu nierealistycznie wysokich standardów wykonania znaczącym innym, przypisywaniu dużego znaczenia temu, czy i w jakim stopniu inni są perfekcyjni oraz dokonywaniu rygorystycznej oceny poziomu wykonania przez nich pracy. Pierwotnie P. Hewitt i G. Flett zwracali uwagę na związek tej formy perfekcjonizmu z tendencją do obwiniania i wykorzystywania innych, brakiem zaufania w relacjach interpersonalnych, poczuciem wrogości, a nawet cynizmem i osamotnieniem oraz problemami w bliskich związkach. Późniejsze badania przeprowadzone przez ten sam zespół badaczy potwierdziły, że partnerzy pacjentów cierpiących na chroniczny ból, którzy cechowali się wysokim poziomem perfekcjonizmu zorientowanego na innych, gorzej oceniali wzajemne dopasowanie w diadzie i rodzinie ${ }^{21}$.

Natomiast perfekcjonizm usankcjonowany społecznie związany jest z przekonaniami dotyczącymi tego, że znaczacy inni mają względem jednostki nierealistycznie wysokie wymagania, oceniają ją w restrykcyjny sposób i wywierają na niej presję, dążąc do tego, aby była perfekcyjna. W związku z tym, że standardy wykonania zadania narzucone przez innych są postrzeganie jako nadmierne i niekontrolowane, wymiar ten może przyczyniać się do powstawania wielu negatywnych konsekwencji w sferze emocjonalnej. Spostrzegana niemożność zaspokojenia żądań innych i przekonanie, że stawiane przez nich wymagania są nierealistyczne, skutkują bowiem doświadczaniem poczucia porażki oraz nasileniem lęku przed ocenąa22.

\section{Perfekcjonizm adaptacyjny i DeZadaptacyjny}

Późniejsze badania empiryczne nawiązujące do wielowymiarowej konceptualizacji perfekcjonizmu P. Hewitta i G. Fletta zasadniczo potwierdzają wstępne założenia autorów modelu, zgodnie z którymi, pomimo znaczących różnic w poszczególnych podskalach, skrajnie wysokie natężenie wszystkich wymiarów perfekcjonizmu stanowi wskaźnik psychopatologii. I tak, społecznie usankcjonowana forma perfekcjonizmu wydaje się odzwierciedlać negatywny, dezadaptacyjny wymiar tej cechy osobowości, wykazując silne i stabilne pozytywne korelacje z neurotyzmem, negatywnym afektem oraz innymi psychologicznymi wyznacznikami nieprzystosowania: lękiem, depresją i myślami samobójczymi²3, zaburzeniami snu ${ }^{24}$, uzależnieniem od ćwiczeń fizycznych ${ }^{25}$, postrzeganą niższą jakością bliskich związków ${ }^{26}$ oraz poczuciem braku umiejętności rozwiązywania problemów w relacjach społecznych, stanowiącą wyznacznik zdrowia psy-

19 P. Hewitt, G. Flett, When does..., dz. cyt., s. 50.

20 P. Hewitt, G. Flett, W. Turnbull-Donovan, S. Mikail, The Multidimensional Perfectionism Scale: reliability, validity, and psychometric properties in psychiatric samples, "A Journal of Consulting and Clinical Psychology" 1991, nr 3(3), s. 464-465.

21 P. Hewitt, G. Flett, S. Mikail, Perfectionism and relationship adjustment in pain patients and their spouses, "Journal of Family Psychology" 1995, nr 9(3), s. 335-339.

22 P. Hewitt, G. Flett, Perfectionism in the self..., dz. cyt., s. 457.

23 J. Stoeber, K. Otto, C. Dalbert, Perfectionism and the Big Five..., dz. cyt., s. 363-365.

24 M. De Azevedo, M. Soares, B. Carvalho, A. Gomes, B. Maia, M. Marques, A. Pereira, A. Macedo, Perfectionism and sleep disturbance, "The World Journal of Biological Psychiatry" 2009, nr 10(3), s. 225.

25 H. Hall, A. Hill, P. Appleton, S. Kozub, The mediating influence of unconditional self-acceptance and labile self-esteem on the relationship between multidimensional perfectionism and exercise dependence, "Psychology of Sport and Exercise" 2009, nr 10, s. 35.

26 M. Haring, P. Hewitt, G. Flett, Perfectionism, coping, and quality in intimate relationships, "Journal of Marriage and Family" 2003, nr 65, s. 143.

OGRody NAUK I SZTUK NR 2014 (4) 
chicznego, a zarazem jeden z czynników przyczyniających się do radzenia sobie ze stresem²7. Ponadto, osoby z wysokim poziomem społecznie usankcjonowanego perfekcjonizmu słabiej oceniały własne umiejętności interpersonalne. Okazały się też $\mathrm{w}$ większym stopniu podatne na doświadczanie różnego rodzaju przejawów niedostosowania psychospołecznego: samotności, nieśmiałości, lęku przed negatywną ocena, a także niskiej samooceny ${ }^{28} . Z$ kolei perfekcjonizm ukierunkowany na innych wymyka się tak jednoznacznym ocenom na wymiarze adaptacyjności-dezadaptacyjności, wykazując zjednej strony dodatni związek z afektem pozytywnym, postępami w osiąganiu celów, a także osiągnięciami akademickimi ${ }^{29}$, a z drugiej z lękiem oraz nasileniem i trwałością symptomów depresyjnych ${ }^{3031}$.

Wyniki wcześniejszych badań empirycznych pokazująjednocześnie, że względnie najbardziej adaptacyjny okazał się perfekcjonizm ukierunkowany na siebie. Wykazywał on bowiem pozytywny związek z postępami w osiaganiu ważnych osobistych celów życiowych oraz redukcją negatywnego afektu ${ }^{32}$. Ponadto, badania longitudinalne przeprowadzone przez Joachima Stoebera, Kathleen Otto i Claudię Dalbert ujawnity, że był on w istotny sposób powiązany z poziomem sumienności jednostki. Badani charakteryzujący się wysokim nasileniem tej cechy osobowości, będąc zorganizowanymi, niezawodnymi i ambitnymi, częściej przejawiali zachowania charakterystyczne dla perfekcjonistów ukierunkowanych na siebie ${ }^{33}$.

Niemniej, jak pokazują wyniki badań przeprowadzonych przez Avi Bessera, G. Fletta i P. Hewitta błędem byłoby utożsamianie perfekcjonizmu ukierunkowanego na siebie wyłącznie z pozytywnym biegunem orientacji perfekcjonistycznej. Jego nasilenie może bowiem modyfikować sposób spostrzegania sytuacji stanowiącej dla jednostki wyzwanie. Wyniki eksperymentu przeprowadzonego przez tę grupę badaczy wskazują bowiem, że po otrzymaniu negatywnej informacji zwrotnej dotyczącej wykonanego zadania perfekcjoniści zorientowani na siebie częściej odczuwali negatywne emocje (lęk, dysforię, wrogość). Charakterystyczne było również dla nich doświadczanie braku satysfakcji z wykonanego zadania, ruminacje odnoszące się do popełnionych błędów oraz irracjonalne przekonania dotyczące ważności niezrealizowanego zadania ${ }^{34}$. Również wcześniejsze badania nie potwierdziły tezy mówiącej o tym, że perfekcjonizm ukierunkowany na siebie odpowiada pozytywnemu, adaptacyjnemu biegunowi tej cechy osobowości. Wręcz przeciwnie, wymiar ten wykazywał pozytywny związek z negatywnym afektem, a także ilością deklarowanych przez badanych objawów psychosomatycznych (w szczególności odczuwanego napięcia i zmęczenia) ${ }^{35}$.

Rezultaty te sugeruja, że wielu zorientowanych na siebie perfekcjonistów, którzy odnieśli porażkę, jest poznawczo zaabsorbowanych poczuciem niemożności osiagnięcia doskonałości, a także skoncentrowanych na wcześniejszych porażkach i błędach. Taki sposób myślenia o sobie sprzyja uwypuklaniu różnicy między ja realnym i idealnym, a w rezultacie kształtowaniu się negatywnej samoświadomości oraz obniżeniu samooceny. Zdaniem A. Bessera, G. Fletta i P. Hewitta skuteczną metodą terapii w takim przypadku mogłyby okazać się interwencje przeprowadzane w nurcie poznawczym, pozwalające na modyfikację negatywnych automatycznych myśli pacjenta $a^{36}$.

Poszczególne wymiary opisywanej cechy osobowości różnią się jednak nie tylko obecnością i nasileniem czynników będących indykatorami psychopatologii, ale też ich etiologią. Wyniki późniejszych badań wskazują na to, że perfekcjonizm ukierunkowany na siebie wykazuje pozytywny związek z wewnętrzną motywacją do nauki, natomiast perfekcjonizm usankcjonowany społecznie koreluje dodatnio z motywacją zewnętrzną. Co więcej, poszczególne komponenty modelu zaproponowanego przez P. Hewitta i G. Fletta również wydają się powiązane w różnym stopniu z poziomem lęku deklarowanego przez osoby badane. Pomimo że zarówno społecznie usankcjonowani perfekcjoniści, jak i zorientowani

27 G. Flett, P. Hewitt, K. Blankstein, M. Solnik, M. van Brunschot, Perfectionism, social problem-solving ability, and psychological distress, "Journal of Rational-Emotive \& Cognitive-Behavior Therapy" 1996, nr 14(4), s. 245-246.

28 G. Flett, P. Hewitt, T. de Rosa, Dimensions of perfectionism, psychosocial adjustment, and social skills, "Personality and Individual Differences" 1996, nr 20(2), s. 143.

29 J. Stoeber, K. Otto, C. Dalbert, Perfectionism and the Big Five..., dz. cyt., s. 363-364.

30 P. Hewitt, G. Flett, Perfectionism in the self..., dz. cyt., s. 457.

31 P. Hewitt, G. Flett, E. Ediger, R. Norton, C. Flynn, Perfectionism in chronic and state symptoms of depression, "Canadian Journal of Behaviour Science" 1998, nr 30(4), s. 234.

32 T. Powers, R. Koestner, R. Topciu, Implementation intentions, perfectionism, and goal progress: perhaps the road to hell is paved with good intentions, "Personality and Social Psychology Bulletin" 2005, nr 31(7), s. 902.

33 J. Stoeber, K. Otto, C. Dalbert, Perfectionism and the Big Five..., dz. cyt., s. 363.

34 A. Besser, G. Flett, P. Hewitt, Perfectionism, cognition, and affect in response to performance failure vs. success, "Journal of Rational-Emotive \& Cognitive-Behavior Therapy" 2004, nr 22(4), s. 320-321.

35 F. Saboonchi, L. Lundh, Perfectionism, anger, somatic health, and positive affect, "Personality and Individual Differences" 2003, nr 35, s. 1594

36 A. Besser, G. Flett, P. Hewitt, Perfectionism, cognition..., dz. cyt., s. 324. 
na siebie cechują się podwyższonym ogólnym poziomem lęku, to jedynie ci drudzy częściej doświadczają negatywnych emocji związanych z zamartwianiem się przyszłymi rezultatami swoich działań. Różnice pomiędzy obydwoma podskalami kwestionariusza MPS zaobserwowano również w odniesieniu do odczuwanego poczucia pewności siebie, które pozytywnie korelowało z perfekcjonizmem ukierunkowanym na siebie, a negatywnie z jego społecznie usankcjonowaną formą. Zależność ta może przyczynić się tym samym do wyjaśnienia roli oczekiwań interpersonalnych dotyczących standardów wykonania przez jednostkę zadania w kształtowaniu się samooceny. O ile bowiem wysokie osobiste standardy realizacji działania łączone z perfekcjonizm ukierunkowanym na siebie wydają się sprzyjać wytrwałości i koncentracji, przyczyniając się zwrotnie do wzmocnienia pewności siebie, o tyle nieadekwatne przekonania dotyczące wymagań stawianych jednostce przez znaczących innych, towarzyszące społecznie usankcjonowanemu aspektowi orientacji perfekcjonistycznej, pełnią zdecydowanie negatywną rolę w kształtowaniu obrazu siebie ${ }^{37}$.

\section{PerfekCjONizm POZYTYWNy I NegATYWNy}

Niejednoznaczność w ocenie dezadaptacyjności poszczególnych rodzajów perfekcjonizmu wyróżnionych w ramach modelu multidymensjonalnego, a także wyniki badań prowadzonych w obszarze psychologii klinicznej i zdrowia, które wskazują na związek tej cechy osobowości z pracoholizmem, zaburzeniami odżywiania czy depresją, przyczyniły się do tego, że część teoretyków podważa zasadność wyróżniania pozytywnych konsekwencji perfekcjonizmu ${ }^{38}$.

Jedną z nowszych alternatywnych koncepcji stanowi unidymensjonalne podejście do perfekcjonizmu autorstwa Rozy Shafran, Zafry Cooper i Christophera Fairburna opracowane - jak piszą badacze - jako rezultat analizy poznawczo-behawioralnej. Posiłkując się wynikami wcześniejszych badań, wskazującymi na bezpośredni związek perfekcjonizmu z zaburzeniami odżywiania takimi jak anoreksja i bulimia, postanowili oni dokonać redefinicji opisywanego zjawiska, zwracając uwagę na znaczenie dążenia do osiagnięcia nadmiernie wygórowanych standardów osobistych w etiologii psychopatologii. W takim ujęciu pojawienie się symptomów choroby stanowi rezultat skłonności do ciągłego modyfikowania i podwyższania nierealistycznych oczekiwań wobec siebie w odpowiedzi na samokrytyczną percepcję własnych działań39. Jednak takie jednowymiarowe ujęcie perfekcjonizmu spotkało się ze zdecydowaną krytyką ze strony zwolenników podejścia wielowymiarowego, według których stanowi ono formę niepotrzebnego redukcjonizmu. Koncentracja na jednostce z pominięciem czynników interpersonalnych wydaje się zubażać rozumienie zjawiska, ponieważ aspekt społeczny odgrywa istotną rolę w powstawaniu psychopatologii ${ }^{40}$.

Zbiorcze analizy wyników badań empirycznych poświęconych tej charakterystyce osobowości wskazują na zasadność rezygnacji z jednoczynnikowych konceptualizacji opisywanego zjawiska, identyfikujących perfekcjonizm z zestawem jednoznacznie negatywnych wzorców zachowania ${ }^{41}$. Ambiwalencja w rozumieniu perfekcjonizmu jako cechy osobowości przekłada się tym samym na rosnącą popularność dychotomicznych koncepcji. Ich autorzy do opisu dwóch przeciwstawnych dymensji używają odmiennych etykietek, wyróżniając perfekcjonizm pozytywny i negatywny, adaptacyjny i dezadaptacyjny, aktywny i pasywny, funkcjonalny i dysfunkcjonalny, a także zdrowy i niezdrowy. Dwuwymiarowy model perfekcjonizmu stał się również podstawą do opracowania Polskiego Kwestionariusza Perfekcjonizmu Adaptacyjnego i Dezadaptacyjnego autorstwa Katarzyny Szczuckiej ${ }^{-42}$.

W takim rozumieniu adaptacyjny perfekcjonizm odpowiada wysokiemu poziomowi sumienności i dążeniu do osiągnięcia sukcesu, a zatem może być traktowany jako pozytywna charakterystyka osobowości. Jednak pomimo dowodów empirycznych wskazujących na istnienie pewnych adaptacyjnych właściwości perfekcjonizmu, część badaczy (przede wszystkim tych prowadzących badania na grupach klinicznych) neguje możliwość wyróżnienia ,,jasnej strony" tego zjawiska. Jak zauważają P. Hewitt i G. Flett granica między tym, co stanowi wyznacznik zdrowia i dobrego przystosowania do środowiska, a psychopatologią w odniesieniu do dążenia do osiągnięć, jest możliwa do ustalenia, a perfekcjonizm jako

37 J. Stoeber, A. Feast, J. Hayward, Self-oriented and socially prescribed perfectionism: differential relationships with intrinsic and extrinsic motivation and test anxiety, "Personality and Individual Differences" 2009, nr 47, s. 423-428.

38 J. Stoeber, K. Otto, Positive conceptions.., dz. cyt., s. 295-319; K. Szczucka, Polski Kwestionariusz..., dz. cyt., s. $72-73$.

39 R. Shafran, Z. Cooper, C. Fairburn, Clinical perfectionism: a cognitive-behavioural analysis, "Behaviour Research and Therapy" 2002, nr 40(7), s. 773.

40 P. Hewitt, G. Flett, A. Besser, S. Sherry, B. McGee, Perfectionism is multidimensional: a reply to Shafran, Cooper and Fairburn (2002), "Behaviour Research and Therapy" 2003, nr 41, s. 221.

41 M. Enns, B. Cox, G. Flett, The nature and assessment of perfectionism: a critical analysis, [w:] P. Hewitt, Perfectionism: theory, research, and treatment, Washington 2002, s. 33-34.

42 K. Szczucka, Polski Kwestionariusz..., dz. cyt., s. 72.

OGRODY NAUK I SZTUK NR 2014 (4) 
neurotyczny styl funkcjonowania jednostki sytuuje się w obszarze psychopatologii. Tym samym wskazanie, w którym momencie sumienność przeradza się w perfekcjonizm nie powinno nastręczać większych trudności. O ile bowiem ten pierwszy związany jest z szeregiem pozytywnym działań podejmowanych przez jednostkę, o tyle drugi przynależy do obszaru psychopatologii, przyczyniając się do doświadczania trudności w relacjach interpersonalnych, depresji, anoreksji i myśli samobójczych. Różnice te wynikają z tego, że perfekcjoniści (w przeciwieństwie do osób o wysokim poziomie sumienności) nie odczuwają satysfakcji w przypadku, gdy dobrze wykonają zadanie, mają małe zdolności organizacyjne, nie potrafią nagradzać siebie i innych w przypadku odniesienia sukcesu. Co więcej, są motywowani strachem przed porażka, a nie pragnieniem sukcesu. Nie potrafią również modyfikować swoich oczekiwań dotyczących standardów wykonania zadania w przypadku pojawienia się trudności i przeszkód. Wszystko to sprawia, że w większym stopniu są narażeni na występowanie problemów zawodowych oraz rodzinnych ${ }^{43}$.

\section{Alternatywne KonCePCJE PERfeKCJONizmu}

Próba integracji różnych wielowymiarowych konstruktów perfekcjonizmu podjęta została przez J. Stoebera i K. Otto. Nawiązując do wcześniejszych konceptualizacji, wyróżnili oni perfekcjonistyczne dążenia i perfekcjonistyczne obawy, sugerując jednocześnie, że ocena adaptacyjności zachowań jednostki powinna być podejmowana w zależności od ich natężenia. Tym samym zdrowy perfekcjonizm charakteryzuje wysoki poziom perfekcjonistycznych dążeń przy niskim poziomie towarzyszących im obaw. W przypadku jego „niezdrowego" odpowiednika zachodzi sytuacja odwrotna" ${ }^{44}$.

Badania przeprowadzone przez J. Stoebera i Juliana Childsa wydają się potwierdzać tę tezę. Perfekcjonistyczne dążenia okazały się bowiem pozytywnie powiązane ze wskaźnikami dobrostanu psychicznego oraz przystosowania do środowiska. Przeciwne zależności odnotowano w przypadku perfekcjonistycznych obaw ${ }^{45}$. Ponadto, perfekcjonistyczne dążenia były związane z wyższym poczuciem dumy wynikającej z odniesionego sukcesu ${ }^{46}$, mniejszym poczuciem winy czy wstydu w przypadku porażki ${ }^{47}$, silniejszym poczuciem własnej skuteczności i podwyższonym poziomem aspiracji ${ }^{48}$, a także nadzieją na osiągnięcie sukcesu oraz obecnością wewnętrznych atrybucji w przypadku odniesienia zwycięstwa ${ }^{49}$. Okazały się one również istotnym predyktorem osiąnięć akademickich, skuteczności w wykonywaniu zadań $\mathrm{w}$ warunkach laboratoryjnych, a także wysokich wyników uzyskiwanych $\mathrm{w}$ testach zdolności stosowanych w obszarze psychologii pracy i organizacji w procesie selekcjij50. Co więcej, badania przeprowadzone wśród studentów pokazują, że wysokie standardy osobiste związane z wykonaniem zadania i skłonność do bycia zorganizowanym, stanowiące przejawy perfekcjonistycznych dążeń, sprzyjają większemu zaangażowaniu. Zaś obawy co do popełnionych błędów oraz słuszności podjętych działań, tradycyjnie kojarzone z negatywnym wymiarem perfekcjonizmu, przyczyniają się do powstawania symptomów wypalenia ${ }^{51}$.

Rozróżnienie wprowadzone przez J. Stoebera i K. Otto nabiera tym samym szczególnego znaczenia w rywalizacji sportowej, pozwalając odróżnić adaptacyjny i dezadaptacyjny wymiar perfekcjonizmu ${ }^{52}$. O ile ten pierwszy wydaje się zasadniczo związany z perfekcyjnymi dążeniami, stanowiącymi przejaw „zdrowego" dążenia do doskonałości, o tyle drugi odpowiada perfekcyjnym obawom, związanym z doświadczaniem wstydu i zażenowania w przypadku porażki ${ }^{53}$. Jednak, jak zauważają G. Flett i P. Hewitt, chociaż perfekcyjne dążenia wśród sportowców mogą prowadzić do spadku

\footnotetext{
43 P. Hewitt, G. Flett, When does..., dz. cyt., s. 50-52.

44 J. Stoeber, K. Otto, Positive conceptions..., dz. cyt., s. 295-319.

45 J. Stoeber, J. Childs, The assessment of self-oriented..., dz. cyt., s. 577.

46 J. Stoeber, T. Kempe, E. Keogh, Facets of self-oriented and socially prescribed perfectionism and feelings of pride, shame, and guilt following success and failure, "Personality and Individual Differences" 2008, nr 44(7), s. 506.

47 J. Stoeber, R. Harris, P. Moon, Perfectionism and the experience of pride, shame, and guilt: comparing healthy perfectionists, unhealthy perfectionists, and nonperfectionists, "Personality and Individual Differences" 2007, nr 43(1), s. 131.

$48 \mathrm{~J}$. Stoeber, J. Hutchfield, K. Wood, Perfectionism, self-efficacy, and aspiration level: differential effects of perffectionistic striving and self-criticism after success and failure, "Personality and Individual Differences" 2008, nr 45(4), s. 323.

49 J. Stoeber, C. Becker, Perfectionism, achievement motives, and attribution of success and failure in female soccer players, "International Journal of Psychology" 2008, nr 43(6), s. 980.

50 J. Stoeber, M. Kersting, Perfectionism and aptitude test performance: testees who strive for perfection achieve better test results, "Personality and Individual Differences" 2007, nr 42, s. 1093.

51 Y. Zhang, Y. Gan, H. Cham, Perfectionism, academic burnout and engagement among Chinese college students: a structural equation modeling analysis, "Personality and Individual Differences" 2007, nr 43, s. 1537.

52 J. Stoeber, K. Otto, Positive conceptions.., dz. cyt., s. 295-319.

53 S. Sagar, J. Stoeber, Perfectionism, fear of failure, and affective responses to success and failure: the central role of fear of experiencing shame and embarrassment, "Journal of Sport \& Exercise Psychology" 2009, nr 31(5), s. 602; J. Stoeber, T. Kempe, E. Keogh, Facets of self-oriented and socially prescribed perfectionism and feelings of pride, shame, and guilt following success and failure, "Personality and Individual Differences" 2008, nr 44(7), s. 1506.
} 
satysfakcji z wykonywanej pracy, to - paradoksalnie - ich brak w niektórych dziedzinach, wymagających od zawodników bezbłędnego wykonania zadania, automatycznie wyklucza szanse jednostki na osiagnięcie zwycięstwa. Zaśs sama wygrana w rywalizacji sportowej niejednokrotnie stanowi swoisty bufor zapobiegający pojawieniu się negatywnych konsekwencji perfekcjonizmu. Związane jest to z tym, że perfekcjoniści mogą nie doświadczać dystresu ani związanych z nim negatywnych konsekwencji swej postawy (takich jak na przykład depresja) w sytuacji, gdy odnoszą sukces. Bowiem kluczowe czynniki modyfikujące relację między perfekcjonizmem a brakiem przystosowania stanowią: umiejętność rozwiązywania problemów oraz zdolność radzenia sobie ze stresem ${ }^{54}$. Dowodów empirycznych potwierdzających prawdziwość tej tezy dostarczyły badania przeprowadzone w populacji ogólnej. Okazało się, że styl unikowy radzenia sobie ze stresem w połączeniu z wysokim poziomem perfekcjonizmu wykazywał pozytywny związek z poczuciem braku nadziei i deklarowanym poziomem dystresu ${ }^{55}$. Co więcej, dezadaptacyjny perfekcjonizm oraz stosowanie nieefektywnych strategii radzenia sobie w grupie osób posiadających unikowy bądź lękowy styl przywiązania okazało się predyktorem depresjij6. Zależność tę wydają się potwierdzać wyniki badań przeprowadzonych przez G. Fletta, A. Bessera i G. Hewitta. Wykazali oni, że stosowanie niedojrzałych, neurotycznych, dezadaptacyjnych mechanizmów obronnych może być zmienną pośredniczącą między deklarowanym przezjednostkęi spostrzeganym przez najbliższego przyjaciela poziomem perfekcjonizmu a depresją ${ }^{57}$.

Dodatkowe trudności związane z konceptualizacją perfekcjonizmu wynikają z faktu, że może on być ograniczony jedynie do wybranych aspektów funkcjonowania jednostki ${ }^{58}$. Innymi słowy, choć niektóre osoby, cechujące się skrajnie wysokim poziomem perfekcjonizmu, manifestują perfekcjonistyczne zachowania we wszystkich sferach swej działalności, zdecydowana większość perfekcjonistów jest perfekcjonistyczna tylko w określonych, istotnych dla ja dziedzinach życia. Na związek perfekcjonizmu z postrzeganiem siebie oraz rozbieżnością między idealnym i realnym obrazem własnej osoby zwrócili również uwagę Nathalie Koivula, Peter Hassmen i Johan Fallby. Wyniki przeprowadzonego przez nich badania na grupie odnoszących sukcesy sportowców pokazały, że czynnikiem modyfikującym adaptacyjność - dezadaptacyjność perfekcjonizmu okazała się pozytywna samoocena. Gdy centralną rolę w jej powstawaniu i podtrzymywaniu odgrywały wartości takie jak miłość i szacunek, perfekcjonizm przybierał pozytywną formę. Natomiast w przypadku, gdy samoocena kształtowała się w oparciu o ocenę własnych kompetencji, jednostka wydawała się manifestować negatywne przejawy perfekcjonizmu ${ }^{59}$.

\section{Podsumowanie}

Perfekcjonizm rozumiany jako cecha osobowości wydaje się złożonym konstruktem. Dotychczasowe próby jego konceptualizacji koncentrowały się na wyróżnieniu pozytywnych i negatywnych aspektów orientacji perfekcjonistycznej. O ile istnienie tych pierwszych nie budzi większych wątpliwości (przynajmniej wśród psychologów klinicznych), o tyle istnienie adaptacyjnych właściwości perfekcjonizmu, począwszy od lat dziewięćdziesiątych ubiegłego wieku, stanowi przedmiot intensywnej debaty. Kwestionowane jest zwłaszcza przekonanie o możliwości jednoznacznego zidentyfikowania "zdrowego" perfekcjonizmu, niezwiązanego z symptomami psychopatologii, w ramach modeli wielowymiarowych $^{61}$. Rozwiązaniem tego dylematu może być przyjęcie ujęcia dychotomicznego $\mathrm{w}$ analizach poświęconych perfekcjonizmowi. Wydaje się to tym bardziej uzasadnione, że badania prowadzone w populacji generalnej wskazują na istnienie grupy perfekcjonistów, którym udało się uniknąć większości negatywnych konsekwencji perfekcjonizmu².

Efektywne funkcjonowanie niektórych jednostek cechujących się wysokim poziomem perfekcjonizmu może być wy-

\footnotetext{
54 G. Flett, P. Hewitt, The perils of perfectionism..., dz. cyt., s. 15-16.

55 R. O'Connor, D. O'Connor, Predicting hopelessness and psychological distress: the role of perfectionism and coping, "Journal of Counseling Psychology" 2003, nr 50, s. 362 .

56 M. Wei, B. Mallinckrodt, D. Russell, T. Abraham, Maladaptive perfectionism as a mediator and moderator between adult attachment and depressive mood, "Journal of Counseling Psychology" 2004, nr 51(2), s. 201.

57 G. Flett, A. Besser, P. Hewitt, Perfectionism, ego defense styles, and depression: a comparison of self-reports versus informant ratings, "Journal of Personality" 2005, nr 73(5), s. 1382.

58 J. Stoeber, F. Stoeber, Domains of perfectionism: prevalence and relationships with perfectionism, gender, age, and satisfaction with life, "Personality and Individual Differences" 2009, nr 46, s. 530.

59 N. Koivula, P. Hassmen, J. Fallby, Self-esteem and perfectionism in elite athletes: effects on competitive anxiety and self-confidence, "Personality and Individual Differences" 2002, nr 32, s. 872-873.

60 A. Bergman, J. Nyland, L. Burns, Correlates with perfectionism..., dz. cyt., s. 389-397; M. Enns, B. Cox, J. Sareen, P. Freeman, Adaptive and maladaptive..., dz. cyt., s. 1034.

61 J. Stoeber, K. Otto, C. Dalbert, Perfectionism and the Big Five..., dz. cyt., s. 363.

62 L. Terry-Short, R. Owens, P. Slade, M. Dewey, Positive and negative perfectionism, "Personality and Individual Differences" 2006, nr 18(5), s.
} 363.

OGRody NAUK I SZTUK NR 2014 (4) 
jaśniane w ramach modelu dwuczynnikowego zaproponowanego przez Petera Slade a i Glynn Owens, którzy zwrócili uwagę na czynniki poznawcze i emocjonalne towarzyszące kształtowaniu się tej cechy osobowości. Pozytywny perfekcjonizm - zgodnie z założeniami tej koncepcji - byłby rezultatem uzyskiwania pozytywnych wzmocnień w toku życia jednostki, zaś negatywny wiązałby się z historią wzmocnień negatywnych. Wzorzec reagowania nabywany w toku uczenia się przyczyniałby się do tego, że pozytywni perfekcjoniści motywowani są pragnieniem osiagnięcia sukcesu, a negatywni lękiem przed porażkąa . Prowadzi to do występowania wśród tych ostatnich dysfunkcji poznawczych takich, jak: ruminacje, wyparcie czy maksymalizacje (dążenie do dokonania możliwie najlepszego wyboru niezależnie od tego, jak wiele opcji pozostało lub zostało już odrzuconych $)^{64}$.

Koncepcja P. Slade a i G. Owensa, wskazująca na znaczenie czynników poznawczo-emocjonalnych w powstawaniu perfekcjonizmu, może tym samym stanowić istotne uzupełnienie innych dychotomicznych modeli, przyczyniając się do lepszego zrozumienia opisywanej cechy osobowości. Irracjonalne i nieadekwatne perfekcjonistyczne przekonania na temat siebie oraz znaczących innych odgrywają bowiem istotną rolę w powstawaniu psychopatologii. Zatem świadomość mechanizmów leżących u podłoża perfekcjonistycznych dążeń i obaw może w znaczącym stopniu przyczyniać się do skuteczności interwencji terapeutycznych ukierunkowanych na redukcję negatywnych aspektów perfekcjonizmu podejmowanych w ramach terapii poznawczo-behawioralnej65.

\section{Bibliografia}

[1] Bergman A., Nyland J., Burns L., Correlates with perfectionism and the utility of a dual process model, "Personality and Individual Differences" $2007, \mathrm{nr} 43$.

[2] Besser A., Flett G., Hewitt P., Perfectionism, cognition, and affect in response to performance failure vs. success, "Journal of Rational-Emotive \& Cognitive-Behavior Therapy" 2004, nr 22(4).

[3] Bouchard C., Rheaume J., Ladouceur R., Responsibility and perfectionism in OCD: an experimental study, "Behaviour Research and Therapy" $1999, \mathrm{nr} 37(3)$

[4] De Azevedo M., Soares M., Carvalho B., Gomes A., Maia B., Marques M., Pereira A., Macedo A., Perfectionism and sleep disturbance, "The World Journal of Biological Psychiatry" 2009, nr 10(3).

[5] Enns M., Cox B., Sareen J., Freeman P., Adaptive and maladaptive perfectionism in medical students: a longitudinal investigation, "Medical Education" 2001, nr 35 .

[6] Enns M., Cox B., Flett G., The nature and assessment of perfectionism: a critical analysis, [w:] Hewitt P., The nature and assessment of perfectionism: A critical analysis. (Ed): Hewitt, P. Perfectionism: Theory, research, and treatment. Washington 2002.

[7] Flett G., Hewitt P., de Rosa T., Dimensions of perfectionism, psychosocial adjustment, and social skills, "Personality and Individual Differences" $1996, \mathrm{nr} 20(2)$.

[8] Flett G., Besser A., Hewitt P., Perfectionism, ego defense styles, and depression: A a comparison of self-reports versus informant ratings, "Journal of Personality" 2005, nr 73(5).

[9] Flett G., Hewitt P., Blankstein K., Solnik M., van Brunschot M., Perfectionism, social problem-solving ability, and psychological distress, "Journal of Rational-Emotive \& Cognitive-Behavior Therapy"1 1996, nr 14(4).

[10] Flett G., Hewitt P., The perils of perfectionism in sports and exercise, . "Current Directions in Psychological Science" 2005, nr 14(1).

[11] Frost R., Marten P., Lahart C., Rosenblate R., The dimensions of perfectionism, "Cognitive Therapy and Research", nr 14(5).

[12] Frost R., Heimerg R., Holt C., Mattia J., Neubauer A., A comparison of two measures of perfectionism, "Personality and Individual Differences" $1993, \mathrm{nr} 14(1)$.

[13] Hall H., Hill A., Appleton P., Kozub S., The mediating influence of unconditional self-acceptance and labile self-esteem on the relationship between multidimensional perfectionism and exercise dependence, "Psychology of Sport and Exercise" 2009, nr 10.

[14] Hamachek D., Psychodynamics of normal and neurotic perfectionism, "Psychology" 1978, nr 15.

[15] Haring M., Hewitt P., Flett G., Perfectionism, coping, and quality in intimate relationships, "Journal of Marriage and Family" 2003, nr 65.

[16] Hewitt P., Caelian C., Flett G., Sherry S., Collins L., Flynn C., Perfectionism in children: associations with depression, anxiety, and anger, "Personality and Individual Differences" $2002, \mathrm{nr} 32$.

[17] Hewitt P., Flett G., Perfectionism in the self and social contexts: conceptualization, assessment, and association with psychopathology, "Journal of Personality and Social Psychology" 1991, nr 60(3).

[18] Hewitt P., Flett G., When does conscientiousness become perfectionism?, "Currrent Psychiatry" 2007, nr 6(7).

[19] Hewitt P., Flett G., Besser A., Sherry S., McGee B., Perfectionism is multidimensional: a reply to Shafran, Cooper and Fairburn (2002), “Behaviour Research and Therapy" 2003, $\mathrm{nr} 41$.

[20] Hewitt P., Flett G., Ediger E., Norton R., Flynn C., Perfectionism in chronic and state symptoms of depression, "Canadian Journal of Behaviour Science" 1998, nr 30(4).

[21] Hewitt P., Flett G., Mikail S., Perfectionism and relationship adjustment in pain patients and their spouses, "Journal of Family Psychology" 1995, nr 9(3).

[22] Hewitt P., Flett G., Sherry S., Habke M., Parkin M., Lam R., McMurtry B., Ediger E., Fairlie P., Stein M., The interpersonal expression of perfection: perfectionistic self-presentation and psychological distress, "Journal of Personality and Social Psychology" 2003, $\mathrm{nr} 84(6)$.

63 P. Slade, R. Owens, A dual process model of perfectionism based on reinforcement theory, "Behavior Modification" 1998, nr 22(3), s. 372.

64 A. Bergman, J. Nyland, L. Burns, Correlates with perfectionism..., dz. cyt., s. 391.

65 P. Hewitt, G. Flett, When does conscientiousness..., dz. cyt., s. 58-59. 
[23] Hewitt P., Flett G., Turnbull-Donovan W., Mikail S., The Multidimensional Perfectionism Scale: reliability, validity, and psychometric properties in psychiatric samples, "A Journal of Consulting and Clinical Psychology" 1991, nr 3(3).

[24] Kawamura K., Frost R., Harmatz M., The relationship of perceived parenting styles to perfectionism, "Personality and Individual Differences" 2002, $\operatorname{nr} 32(2)$.

[25] Koivula N., Hassmen P., Fallby J., Self-esteem and perfectionism in elite athletes: effects on competitive anxiety and self-confidence, "Personality and Individual Differences" 2002, nr 32 .

[26] O'Connor R., O'Connor D., Predicting hopelessness and psychological distress: the role of perfectionism and coping, "Journal of Counseling Psychology" 2003, nr 50

[27] Powers T., Koestner R., Topciu R., Implementation intentions, perfectionism, and goal progress: Perhaps perhaps the road to hell is paved with good intentions, "Personality and Social Psychology Bulletin" 2005, nr 31(7).

[28] Rice K., Ashby J., Stanley R., Self-esteem as a mediator between perfectionism and depression: a structural equations analysis, "Journal of Counseling Psychology" 1998, nr 45(3).

[29] Saboonchi F., Lundh L., Perfectionism, anger, somatic health, and positive affect, "Personality and Individual Differences" 2003, nr 35.

[30] Sagar S., Stoeber J., Perfectionism, fear offailure, and affective responses to success and failure: the central role offear of experiencing shame and embarrassment, "Journal of Sport \& Exercise Psychology" 2009, nr 31(5).

[31] Sassaroli S., Lauro L., Ruggiero G., Mauri M., Vinai P., Frost R., Perfectionism in depression, obsessive-compulsive disorder and eating disorders, "Behaviour Research and Therapy" 2008, nr 46.

[32] Shafran R., Cooper Z., Fairburn C., Clinical perfectionism: a cognitive-behavioural analysis, "Behaviour Research and Therapy" 2002, nr 40(7).

[33] Sherry S., Hewitt P., Flett G., Lee-Baggley D., Hall P., Trait perfectionism and perfectionistic self-presentation in personality pathology, "Personality and Individual Differences" 2007, $\mathrm{nr} 42$.

[34] Slade P., Owens G., A dual process model of perfectionism based on reinforcement theory, "Behavior Modification" 1998, nr 22(3).

[35] Soenens B., Elliot A., Goossens L., Vansteenkiste M., Luyten P., Duriez B., The Intergenerational transmission of perfectionism: parents' psychological control as an intervening variable, "Journal of Family Psychology" 2005, nr 19(3).

[36] Stoeber J., Becker C., Perfectionism, achievement motives, and attribution of success and failure in female soccer players, "International Journal of Psychology" 2008, nr 43(6)

[37] Stoeber J., Feast A., Hayward J., Self-oriented and socially prescribed perfectionism: differential relationships with intrinsic and extrinsic motivation and test anxiety, "Personality and Individual Differences" 2009, nr 47.

[38] Stoeber J., The Frost Multidimensional Perfectionism Scale: more perfect with four (instead of six) dimensions, "Personality and Individual Differences" 1998, nr 24(4)

[39] Stoeber J., Childs J., The assessment of self-oriented and socially prescribed perfectionism: Subscales subscales make a difference, "Journal of Personality Assessment" 2010, nr 92(6).

[40] Stoeber J., Eysenck M., Perfectionism and efficiency: accuracy, response bias, and invested time in proof-reading performance, "Journal of Research in Personality" 2008, nr 42(6)

[41] Stoeber J., Harris R., Moon S., Perfectionism and the experience of pride, shame, and guilt: comparing healthy perfectionists, unhealthy perfectionists, and nonperfectionists, "Personality and Individual Differences" 2007, nr 43(1).

[42] Stoeber J., Hutchfield J., Wood K., Perfectionism, self-efficacy, and aspiration level: differential effects of perfectionistic striving and self-criticism after success and failure, "Personality and Individual Differences" 2008, $\mathrm{nr} 45(4)$.

[43] Stoeber J., Kempe T., Keogh, E., J. (2008). Facets of self-oriented and socially prescribed perfectionism and feelings of pride, shame, and guilt following success and failure, "Personality and Individual Differences" 2008, nr 44(7).

[44] Stoeber J., Kersting M., Perfectionism and aptitude test performance: testees who strive for perfection achieve better test results, "Personality and Individual Differences" 2007, $\mathrm{nr} 42$.

[45] Stoeber J., Otto K., (2006). Positive conceptions of perfectionism: approaches, evidence, challenges, "Personality and Social Psychology Review" 2006, nr 10.

[46] Stoeber J., Otto K., Dalbert C., Perfectionism and the Big Five: conscientiousness predicts longitudinal increases in self-oriented perfectionism, "Personality and Individual Differences" 2009, nr 47(4).

[47] Stoeber J., Stoeber F., Domains of perfectionism: prevalence and relationships with perfectionism, gender, age, and satisfaction with life, "Personality and Individual Differences" 2009, nr 46.

[48] Stoeber J., Stoll O., Pescheck E., Otto K., Perfectionism and achievement goals in athletes: relations with approach and avoidance orientations in mastery and performance goals, "Psychology of Sport and Exercise" 2008, nr 9(2).

[49] Szczucka K., Polski Kwestionariusz Perfekcjonizmu Adaptacyjnego i Dezadaptacyjnego,., „Psychologia Społeczna” 2010, nr 5.

[50] Terry-Short L., Owens R., Slade P., Dewey M., Positive and negative perfectionism, "Personality and Individual Differences" 2006, nr 18(5).

[51] Wei M., Mallinckrodt B., Russell D., Abraham T., Maladaptive perfectionism as a mediator and moderator between adult attachment and depressive mood, "Journal of Counseling Psychology" 2004, nr 51(2).

[52] Winter R., W pułapce perfekcjonizmu: prosta droga do porażki, Kraków 2013.

[53] Yang H., Stoeber J., The Physical Appearance Perfectionism Scale: development and preliminary validation, "Journal of Psychopathology and Behavioral Assessment" 2012, nr 34(1).

[54] Zhang Y., Gan Y., Cham H., Perfectionism, academic burnout and engagement among Chinese college students: a structural equation modeling analysis, "Personality and Individual Differences" 2007, nr 43. 